\title{
The Influence of Leadership and Work Motivation on Work Effectiveness through Discipline
}

\author{
Kasmiaty, Baharuddin, and Muhammad Nur Fattah \\ Sekolah Tinggi Ilmu Ekonomi AMKOP Makassar, Indonesia \\ kasmiaty@gmail.com, baharuddinamkop@gmail.com,fattahnur@yahoo.com \\ Nasaruddin $\mathbf{H}$ \\ STISIP 17-8-1945 Makassar, Indonesia \\ nazhar111281@gmail.com \\ Yusriadi Yusriadi \\ Sekolah Tinggi Ilmu Administrasi Puangrimaggalatung, Makassar, Indonesia \\ yusriadi.yusriadi@uqconnect.edu.au \\ Muh Ilham Usman \\ Sekolah Tinggi Agama Islam Negeri Majene \\ ilhamusman@stainmajene.ac.id \\ Suherman \\ STIAB Smaratungga \\ herusuhermanlim@gmail.com
}

\begin{abstract}
This type of research used in this study is associative research. The research site is located at the Department of Education and Culture, Soppeng Regency. The sample used the census method, which an entire population of as many as 112 employees. In conducting statistical testing, it uses path analysis. The results showed that leadership positively and significantly affected employee discipline in the Department of Education and Culture in Soppeng Regency. Work motivation has a positive and significant effect on employee discipline in the Department of Education and Culture in Soppeng Regency. This study's result is: 1) Leadership has a positive and significant impact on the Soppeng District Education and Culture Office's work effectiveness. 2) Work motivation has a positive and significant impact on the Soppeng District Education and Culture Office's efficacy. 3) Employee discipline has a positive and significant effect on the Department of Education and Culture's work effectiveness in Soppeng Regency. 4) Leadership has a positive and significant impact on work effectiveness through employee discipline at the Department of Education and Culture in Soppeng Regency. 5) Work motivation has a positive and significant effect on work effectiveness through employee discipline at the Department of Education and Culture in Soppeng Regency.
\end{abstract}

Keywords: Leadership, Work Motivation, Work Effectiveness, Employee Discipline

\section{Introduction}

Globalization presents several challenges related to human resource (HR) management. Every organization must have qualified and highly competitive human resources to be energy for the organization to compete with its competitors during increasingly dynamic changes. The demands of talented and competitive human resources are competing organizations' needs and their own customers' demands, primarily external customers. Currently, the organization's external customers face many alternative decision-making choices so that they have many options in determining which products and services are consumed.

Human resource management is an essential element in the management function. If human resources are not managed properly, their effectiveness will decline more rapidly than other resources. Human resources have a more significant 
influence on organizational effectiveness than any additional help. Therefore, in the current global era, human resource management activities will effectively increase at all organizations' types and levels. This is a consequence of the progress and developments taking place today in the fields of science and technology, business, and other life. And human resource management techniques will also be made easier thanks to the continued advancement of science and technology. Therefore, people who work in an organization will further improve their quality, which is one factor that determines the effectiveness of employee work.

AH. Rahadian and Mila Kencana (2016), where the study results show that there is a positive and significant influence of discipline on the effectiveness of natural disaster management work in Sukamakmur District, Bogor Regency. A positive and significant impact on Discipline and Discipline together on the efficacy of natural disaster management work in Sukamakmur District, Bogor Regency.

Based on the phenomenon and the results of the researcher interviews that the work effectiveness of employees at the Office of Education and Culture of Soppeng Regency is still considered not optimal or not as expected. Based on preliminary observations, the author found that employees in carrying out main tasks or tasks and assignments cannot complete the work on time. According to predetermined targets, (2), there is still a lack of cooperation in completing work where some employees do not think that the result is a system, (3). The level of discipline in terms of attendance during working hours there are still employees who are late coming or attending apples and in the order without filling. The author suspects that employees' work effectiveness is not as expected because of leadership and work discipline, and motivation cannot support the point of employees' work. This will impact the achievement of organizational goals because the effectiveness of work quality is undoubtedly the hope of every organization.

\section{Literature Review}

According to Judge (2007), the definition of motivation states that motivation is an impulse that causes someone to take any action to achieve specific goals. The motivational question is how to encourage subordinates' enthusiasm so that they are willing to work hard by giving all their abilities and skills to realize the company's goals. Meanwhile, motivation is the driving force that causes an organization member to be willing and willing to take the time to carry out various activities that are their responsibility and fulfill their obligations to achieve the organization's goals and objectives that have been previously set (Siagian, 2010; Nuraini et al., 2019; Umanailo, 2020, 2019).

Motivation comes from the Latin word "Movere" which means encouragement or driving force. This motivation is only given to humans, especially to subordinates or followers. Motivation questions how to encourage their subsidiaries' morale so that they are willing to work hard by providing all their abilities and skills to achieve company goals. Companies expect capable, capable, and skilled employees, but most importantly, they are willing to work hard and achieve optimal work results. The following are some opinions of experts regarding the definition of work motivation, among others: motivation is the provision of a driving force that creates a person's enthusiasm for work so that they are willing to work together, work effectively, and be integrated with all their efforts to achieve satisfaction". According to Wibowo (2010) "motivation is an impetus for a series of processes of human behavior in achieving goals". While the elements contact the same time, motivation includes arousing, directing, maintaining, showing intensity, being continuous and having a purpose. Motivation is the factors that control and encourage a person's behavior or desire to carry out an activity that is expressed in the form of hard or weak efforts".

Work motivation is something that gives rise to work motivation or enthusiasm. Work motivation is a driving force or impetus in a person to want to behave and work actively and competently following the duties and obligations that have been given to him (Kanto et al., 2020; Lionardo et al., 2020; Rachman et al., 2019). Work motivation can be defined as a psychological boost to someone who determines the direction of a person's behavior in the organization, the level of effort, and the level of persistence or resilience in the face of an obstacle or problem (level of diligence). Based on the opinion of experts regarding work motivation, work motivation is an encouragement for employees who generate enthusiasm for work to work better in achieving goals.

Companies carry out environmental protection as a form of social control that focuses on sustainable development. The environment in which the business is located must be maintained so that no damage occurs. Thus, It can also guarantee the company's existence. For example, It must first neutralize the management of waste generated as a residue from the production process before being disposed of. b) Employee protection and guarantees. Without company employees, they are certainly unable to carry out their activities. Employee welfare is an absolute measure that is the benchmark for the company in appreciating its employees. When employees feel that they are in synergy 
with the company, this will positively impact the company. The company provides appropriate rewards, so employees will make positive contributions and work hard for the company that has served them well-for example, training. The role of the community in determining company policies is important. So that the company and the surrounding community must maintain harmony in order to work together. When local people boycott the existence of this company it is a serious problem for business sustainability. Examples of activities that can accommodate this factor are hiring natives or local residents.

\section{Work Discipline}

Discipline is an attitude of respect, respect, obedience, and obedience to the applicable regulations, both written and unwritten, and carrying them out and not being spared from sanctions. If they violate the duties and authorities given to them, conditions that cause/encourage employees to do and do all activities follow established norms/regulations. Therefore, work discipline is essentially persistence, obedience, training, and a very respectful attitude that appears to be following the rules that have been mutually agreed upon between the organization and its employees. Besides, it can also be said that discipline is an effort to instill value in creating an attitude of obeying specific work rules and being responsible for their work.

The principle of including means inviting subordinates to participate and propose ideas and recommendations in the decision-making process. In this way, associates feel partially responsible for achieving company goals so that their morale and work enthusiasm will increase. The principle of communication means to inform plans to be completed, how to do them, and their obstacles. With the direction of contact, the work motivation of subordinates will increase. Because the more someone knows a problem, the greater their interest and attention to it. If a leader makes an effort to keep his subordinates informed, he will say, "I think you are an important person; I want to make sure you know what is going on." In this way, subordinates will feel appreciated and will work harder. The principle of recognition means giving appropriate and fair rewards and recognition to subordinates for their work achievements. The assistants will work harder and diligently if they continue to receive glory and satisfaction from their efforts. Giving recognition/praise to subordinates should explain that he deserves the award because of the work performed or services he has provided. Recognition and credit must be given sincerely in public so that the recognition/praise can get bigger.

\section{Employee Work Effectiveness}

Effectiveness is an expectation that provides an overview of the extent to which these targets can be achieved (Umar, 2003; Mu'adi et al., 2020; Nawawi et al., 2020). In the experts' opinion above, it can be concluded that a job can be carried out appropriately, effectively, and efficiently if the work is carried out appropriately as planned. The effectiveness of the work is none other than one or several. Society, especially employees in an organizational unit or company, can carry out the goals achieved in a system that is determined with a view to meeting the needs of the system itself. Effectiveness is the ability of a person or several people in a group or organization to give birth to use or benefit from what is done.

The word practical comes from English, namely effective, which means successful or done successfully. Popular scientific dictionaries define effectiveness as the appropriateness of use, use results, or support goals. Effectiveness comes from the word "effect," and this term is used as a causal relationship. Effectiveness can be seen as a cause of other variables. Effectiveness means that the goals that have been planned before can be achieved, or in other words, the target is achieved because of the activation process. Effectiveness is the ability to carry out tasks, functions (program activity operations or missions) of an organization or the like where there is no pressure or tension between its implementations. Effectiveness is a communication whose process achieves the planned objectives according to budgeted costs, the set time, and the specified number of personnel. Based on the above opinion, effectiveness is communication that goes through a particular process in a measurable way, namely the achievement of predetermined goals or objectives. With the budgeted costs, a fixed time, and a predetermined number of people. If these provisions run smoothly, the planned objectives will be achieved as desired.

Measuring organizational effectiveness is not a very simple matter because effectiveness can be studied from various perspectives and depends on who assesses and interprets it. When viewed from a productivity point of view, a production manager understands that effectiveness means the quality and quantity (output) of goods and services. It can also measure the level of effectiveness by comparing the plans that have been determined with the tangible results that have been realized. However, if the effort or work results and the actions taken are not appropriate, causing the goal not to be achieved or the expected target, it is said to be ineffective. The criteria or measures regarding the achievement of practical or not goals are: (1) Clarity of the objectives to be achieved, so that in their implementation 
they can achieve organizational goals and targeted goals; (2) Clarity of strategies to achieve goals, in making various efforts to achieve specified targets so as not to get lost in achieving organizational goals; (3) A solid process of analysis and formulation of policies, relating to the objectives to be achieved and the strategies that have been determined means that policies must be able to bridge these goals with the implementation efforts of operational activities; (4) Careful planning, proper programming, a good plan still needs to be translated into appropriate implementation programs because if not, the implementers will lack guidelines for acting and working; (5) Availability of work facilities and infrastructure. Indicators of organizational effectiveness are the ability to work productively; (6) Effective and efficient implementation, however good a program is, if it is not implemented effectively and efficiently, the organization will not achieve its goals; and (7) Supervising and controlling educational systems, given imperfect human nature, the effectiveness of the organization requires the existence of a supervisory and control system.

\section{Methods}

The research design is a survey, which entails analyzing facts and data to support the information required to keep the research discussion to solve and answer the main problems proposed, namely the influence of employee competence and office work facilities on service quality through employee performance. This is a quantitative research approach. Quantitative research methods are used to test theories by studying the relationship between variables. Survey research analyzes facts and data that support the information needed to help research discussions with a quantitative approach. The quantitative research approach is a method of testing specific theories by examining the relationship between variables. Data collection is done to gather information needed to meet research goals. For example, this study requires data on the impact of employee competency and office work facilities on service quality as measured by employee performance. The interview is one of the data gathering strategies done face-to-face with the resource person through direct question and answer; data gathered directly with employees as respondents by asking frequent questions. The data collection strategy that it will employ in this study is a list of questions administered personally. It gathered data through a closed questionnaire; a questionnaire used to collect information on staff skills, office work facilities, and employee performance to improve service quality. The questionnaire employed in this study is a direct and closed questionnaire, which means that it is delivered to the respondent directly, and the respondent can select one of the available possible replies. This study's population was all employees of the Education and Culture Office of Soppeng Regency, totaling 112 employees.

\section{Result}

Path Analysis Model According to (Kerlinger 2006), path analysis is an applied form of multiple regression analysis. Path diagrams help conceptualize problems or test complex hypotheses (Ghozali 2011), explaining that path analysis further develops various linear regression analyses and bivariate regression. Path analysis examines regression equations involving multiple exogenous and endogenous variables at the same time to allow testing of the mediating/intervening or intermediate variables. Besides, path analysis can measure the direct and indirect relationships between variables in the model.

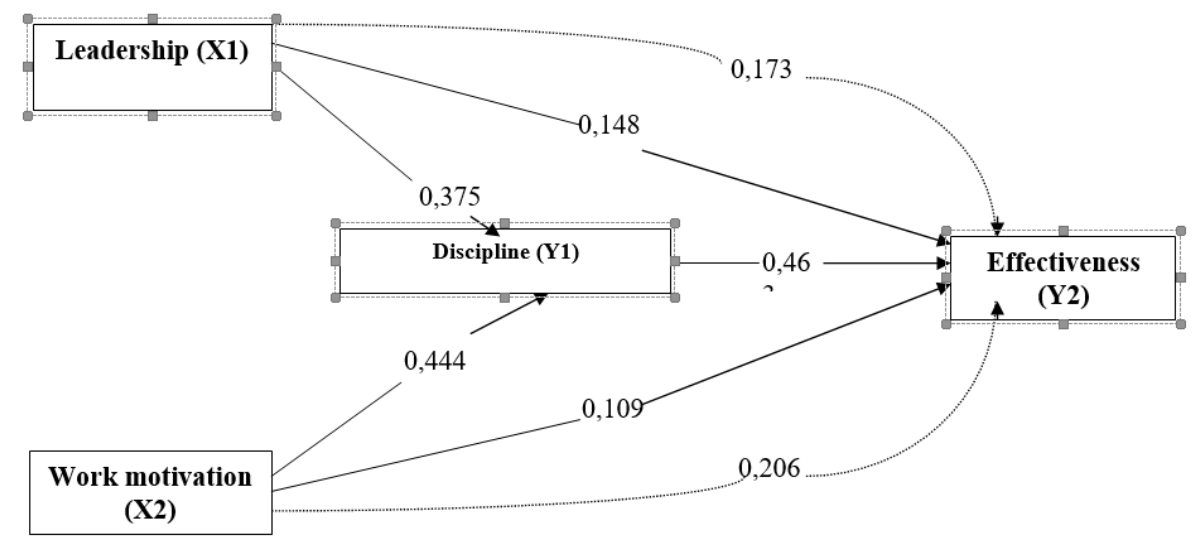

Figure 1. Path analysis model

From the path analysis model, the path analysis equation formed is as follows:

$\mathrm{Y} 1$

Y1 
$\mathrm{Y} 2$

$\mathrm{Y} 2$

$\mathrm{Y} 2=\mathrm{f}(\mathrm{X} 1, \mathrm{X} 2)$

$=\alpha 0+\alpha 1 \mathrm{X} 1+\alpha 2 \mathrm{X} 2+\mathrm{e} 1$

$=\mathrm{f}(\mathrm{X} 1, \mathrm{X} 2, \mathrm{Y} 1)$

$=\beta 0+\beta 1 \mathrm{X} 1+\beta 2 \mathrm{X} 2+\beta 3 \mathrm{Y} 1+\mathrm{e} 2$

$=\beta 0+\beta 1 \mathrm{X} 1+\beta 2 \mathrm{X} 2+\beta 3 \mathrm{Y} 1(\alpha 0+\alpha 1 \mathrm{X} 1+\alpha 2 \mathrm{X} 2+\mathrm{e} 1)+\mathrm{e} 2$

Where:

Y1

$\mathrm{Y} 2$

$\alpha 0 ; \beta 0$

$\mathrm{X} 1$

$\mathrm{X} 2$

$\alpha 1, \alpha 2, \beta 1, \beta 2, \beta 3$

$\mathrm{e} 1, \mathrm{e} 2=$ Discipline

$=$ Work Effectiveness

$=$ constant

$=$ Leadership

$=$ Work Motivation

$=$ path line coefficient

$=$ error or confounding variable

4.1 The Influence of Leadership on Employee Discipline

The results of testing the first hypothesis show that leadership has a positive and significant effect on employee discipline. The value of count 3,930 indicates this $>t$ table 1,982 with a significance value of 0,000 . This suggests that the organization gives the more appropriate leadership.

Table 1. Reliability Test Results

\begin{tabular}{|l|c|c|}
\hline \multicolumn{1}{|c|}{ Variable } & Cronbach Alpha $(\boldsymbol{a})$ & Conclusion \\
\hline Competency $(\mathrm{X} 1)$ & 0,690 & Reliable \\
\hline Work Facility $(\mathrm{X} 2)$ & 0,787 & Reliable \\
\hline Performance $(\mathrm{Z})$ & 0,780 & Reliable \\
\hline Work Quality (Y) & 0,812 & Reliable \\
\hline
\end{tabular}

Source: Processed primary data

Testing the first hypothesis shows that work motivation has a positive and significant effect on employee work discipline. The amount of count 4,650 indicates this $>t$ table 1,982 with a significance value of 0,000 . This shows that the higher the employee work motivation, the employee discipline at the Education Office and Soppeng Regency culture will increase. Vice versa, if the employee's work motivation is lower, the employee discipline will also be more insufficient. Testing the first hypothesis shows that leadership has a positive and significant effect on employee work effectiveness. The Education and Culture Office of Soppeng Regency will increase, and vice versa. If the supervision provided is not appropriate, the work effectiveness of employees will also be lower. Testing the first hypothesis indicates that work motivation has a positive and significant effect on employee work effectiveness. This is indicated by the value of $t$ count $1.996>t$ table 1.982 with a significance value of 0.046 . Soppeng will increase, and vice versa if the employee's work motivation is lower, the employee's work effectiveness will also be lower.

\subsection{The Effect of Discipline on Employee Work Effectiveness}

Testing the first hypothesis shows that discipline has a positive and significant effect on employee work effectiveness. This is indicated by the count value of $3.303,>t$ table 1.982 with a significance value of 0.023 . The culture of Soppeng Regency will increase, and vice versa if the employee discipline is low, the employee's work effectiveness will also be lower.

Testing the sixth hypothesis shows that leadership has a positive and significant effect on work effectiveness through employee work discipline. This offers the direct effect value of 0.148 while the indirect impact is 0.173 , meaning that the immediate effect's value is smaller than the value of the indirect impact. This shows that leadership's influence on 
Proceedings of the International Conference on Industrial Engineering and Operations Management Sao Paulo, Brazil, April 5 - 8, 2021

employee work effectiveness through discipline has a positive and significant impact. The more effective the employee leadership discipline will increase, the more influential the employee's work at the Education and Culture Office of Soppeng Regency will also increase.

Table 2. Validity Test Results

\begin{tabular}{|c|c|c|c|c|}
\hline Variable & Question Items & r count & r table & Conclusion \\
\hline \multirow{3}{*}{ Competency (X1) } & Item 1 & 0,637 & \multirow{3}{*}{0,264} & Valid \\
\hline & Item 2 & 0,758 & & Valid \\
\hline & Item 3 & 0,509 & & Valid \\
\hline \multirow{4}{*}{ Work Facility (X2) } & Item 1 & 0,668 & \multirow{4}{*}{0,264} & Valid \\
\hline & Item 2 & 0,817 & & Valid \\
\hline & Item 3 & 0,676 & & Valid \\
\hline & Item 4 & 0,787 & & Valid \\
\hline \multirow{5}{*}{ Performance $(\mathrm{Z})$} & Item 1 & 0,664 & \multirow{5}{*}{0,264} & Valid \\
\hline & Item 2 & 0,756 & & Valid \\
\hline & Item 3 & 0,772 & & Valid \\
\hline & Item 4 & 0,854 & & Valid \\
\hline & Item 5 & 0,638 & & Valid \\
\hline
\end{tabular}

Source: Processed primary data

Testing the sixth hypothesis shows that leadership positively and significantly affects work effectiveness through work discipline. This indicates that the direct effect value is 0.109 while the indirect effect is 0.206 . This means that the value of the immediate impact is smaller than the value of the indirect impact. This shows that leadership's influence on employee work effectiveness through work motivation has a positive and significant effect. Based on this, if leadership is effective, employee work discipline will also increase, so that the work effectiveness of employees at the Soppeng Education and Culture Office will also increase.

\section{Discussion}

Leadership is regarded as a fundamental driving force for businesses to establish a new culture conducive to change. Many people believe that leadership is directly tied to an organization's success. Leaders in an organization have a disproportionate influence on the organization's success or failure. An organization's performance is a description of the leader's performance in managing the organization. A good leader will guide, persuade, and monitor others to carry out tasks following his directions to realize organizational goals.

Managers' ability and leadership skills in direction are critical factors in their performance. The organization's ability to pick influential leaders will improve if it can identify the attributes connected with leadership. And, if the organization can discover effective leadership behaviours and strategies, it will accomplish personal effectiveness development in the organization. The ability of the leaders and their supporters demonstrates that human resources are vital in government since government activities are primarily dependent on the activities of the apparatus as members of government organizations. Then, based on the operations of the government machinery, its efficacy in achieving government objectives and efficiency in utilizing the resources at its disposal may be seen. This suggests that the leader's competence to manage resources is required to fulfil the company's goals or improve organizational performance.

The quality of the leader is frequently seen as an essential aspect in the organization's success or failure, as well as the success or failure of an organization, both corporate and public focused, is usually recognized as the success or failure of the leader. The leader's job is so crucial that it has become a focus of interest for researchers in the field of organizational behaviour. Leaders are critical in developing and implementing corporate strategies. As a result, every leader is obligated to devote substantial attention to designing, mobilizing, and guiding all potential employees in their environment to realize the volume and workload oriented toward the goal. In addition, leaders must provide authentic coaching to employees to increase employee satisfaction and organizational commitment and promote high performance. 


\section{Conclusion}

Effective leadership will further increase employee discipline and vice versa the less effective leadership. The employee discipline will also below in the Education and Culture Office of Soppeng Regency. High work motivation will increase employee discipline and vice versa, the lower work motivation, the employee discipline will also below in the Office of Education and Culture of Soppeng Regency Leadership Effective leadership will increase employee work effectiveness and vice versa the more ineffective leadership. The employee work effectiveness will also below in the Office of Education and Culture of Soppeng Regency. Higher work motivation will further increase employee work effectiveness and vice versa. Lower work motivation will reduce the work effectiveness of employees at the Office of Education and Culture of Soppeng Regency. The higher the level of discipline, the more influential the employee's work effectiveness, and vice versa, the lower the domain, the work effectiveness. The significance of staff will also be expected in the Education and Culture Office of Soppeng Regency. If the leadership is effective, then employee discipline will increase so that employees' work effectiveness at the Education and Culture Office of Soppeng Regency will also increase. If the motivation for work is high, employee discipline will increase so that employees' effectiveness at the Education and Culture Office of Soppeng Regency will also increase.

\section{References}

Abdurahman and Muhidin. 2007. Correlation, Regression, and Path Analysis in Research. Bandung: Reader Setia.

Creswell, J. W. (2010). Research design: qualitative, quantitative, and mixed approaches. Yogjakarta: PT Student Library.

Fathoni, Abdurrahmat. 2006. Human Resources Organization and Management. Jakarta: Rineka Cipta.

Ferdinand 2011, Management Research Methods Research Guidelines for Thesis, Thesis, and Dissertation Management Science Writing, Issue 3, AGF Books, Faculty of Economics and Business, Diponegoro University, Semarang.

Ghozali, Imam. 2011. "Multivariate Analysis Application with SPSS Program". Semarang: Diponegoro University Publisher Agency.

Heryati.2015. Service Quality, Store Atmosphere, Private Brand on Customer Satisfaction and Loyalty of Hypermart Puri Jakarta. Journal of Communicology. Vol. 12, No. 1

Huitt, W. 2008. http://sunartombs.wordpress.com/2008/09/23/motivation-learning/ (accessed 02 May 2012).

Indriantoro, Nur., Bambang Supomo, 2009. Business Research Methodology for Accounting and Management, First Edition. Yogyakarta: BPFE Yogyakarta.

Jones. 2002. Understanding and Managing Organizational Behavior. New Jersey: Prentice Hall

Kaloh, J. 2009. Leadership of Regional Heads. (Pattern of Activities, Power and Behavior of Regional Heads in the Implementation of Regional Autonomy). Jakarta: Sinar Grafika.

Kanto, S., Wisadirana, D., Chawa, A. F., \& Umanailo, M. C. B. (2020). Change in community work patterns. Proceedings of the International Conference on Industrial Engineering and Operations Management, 0(March), 2496-2502.

Lionardo, A., Kurniawan, R., \& Umanailo, M. C. B. (2020). An effectiveness model of service policy of building permit (IMB) based on a green spatial environment in palembang city. Proceedings of the International Conference on Industrial Engineering and Operations Management, 2588-2596.

Manopo, Jirre Victori.2014. The Role of Organizational Communication in Shaping the Effectiveness of Employee Work CV. Magnum Sign and Print Advertising Samarinda.eJournal of Communication Studies. ISSN 00000000. 357-372

Moenir U.S., 1987; Humane and Organizational Approaches to Staffing Development, Jakarta, Sinar Grafika.

Moenir, H.AS, Management of Public Services in Indonesia, Bumi Aksara. Jakarta 2008

Mu'adi, S., Maksum, A., Hakim, M. L., \& Umanailo, M. C. B. (2020). Transfer of function agricultural land. Proceedings of the International Conference on Industrial Engineering and Operations Management, 0(March), 2568-2574.

Nawawi, M., Ali, A., Irawan, B., Ahmad, B., Mukramin, S., Marsuki, N. R., Umanailo, M. C. B., \& Kaya, I. R. G. (2020). The village kalesang program as a poverty alleviation community. International Journal of Scientific and Technology Research, 9(3), 3103-3107.

Now, Uma. 2013. Research Methodology for Business (Research Methods for Business). Book 1 Issue 4. Horizon: Fourth Salemba 
Nuraini, N., Riadi, A., Umanailo, M. C. B., Rusdi, M., Badu, T. K., Suryani, S., Irsan, I., Ismail, I., Pulhehe, S., \& Hentihu, V. R. (2019). Political Policy for the development of Education. International Journal of Scientific \& Technology Research, 8(10).

Prasetyo, Bambang, Lina Miftahul jannah, Quantitative Research Methods: Theoretical Applications, Jakarta: PT Raja Grafindo Persada, 2008.

Rachman, S., Hamiru, H., Umanailo, M. C. B., Yulismayanti, Y., \& Harziko, H. (2019). Semiotic Analysis of Indigenous Fashion in The Island of Buru. International Journal of Scientific \& Technology Research, 8(8), $1515-1519$.

Umanailo, M. C. B. (2019). Structure of Social Change in Industrial Society. Proceedings of the International Conference on Industrial Engineering and Operations Management Riyadh, 668-672.

Umanailo, M. C. B. (2020). The energy in the context of social. Proceedings of the International Conference on Industrial Engineering and Operations Management, 0(March), 2503-2508.

Veithzal Rivai,, 2005. Human Resource Management for Companies, from Practical Teorike, PT. Raja Grafindo Persada, Jakarta.

Winarno, Budi; 2014; Public Policy: Theory, Process and Case Study; Yogyakarta; Center of Academic Publishing Service (CAPS).

\section{Biographies}

Kasmiaty is a student at Magister Program of Economic Science of STIE AMKOP, Indonesia. Her areas of interest and research include social science and economic. She has published some articles in national journals.

Baharuddin is a lecturer at Economics Department of STIE AMKOP, Indonesia. His areas of interest and research include economic, management, management human resource. He has published some books and many articles in national and international journals.

Muhammad Nur Fattah is a lecturer at Economics Department of STIE AMKOP, Indonesia. His areas of interest and research include economic, management, management human resource. He has published some books and many articles in national and international journals.

Nasaruddin H is a lecturer at STISIP 17-8-1945 Makassar, Indonesia. His areas of interest and research include include social science, political science, and sociology. He has published many articles in national and international journals.

Yusriadi Yusriadi is a lecturer at Public Administration Department of Sekolah Tinggi Ilmu Administrasi Puangrimaggalatung, Indonesia and chancellor on Sekolah Tinggi Ilmu Hukum Pengayoman. His areas of interest and research include social science, political science, sociology, legal studies, and public administration. He has published some books and many articles in national and international journals. He is a reviewer and editor in some local and international journals.

Muh. Ilham Usman has worked as a lecturer at the Qur'anic Studies Program, Department Ushuluddin, Adab dan Dakwah Majene State Islamic College since 2018 until now in the College's academic activities. Completed the master program in the Islamic Studies at Postgraduate Program Alauddin State Islamic University in 2010, a thesis Nahdlatul Ulama's Transformative Theology in Indonesia.

Suherman, Head of PostGraduate at STIAB Smaratungga, Boyolali, Central Java. He completed his bachelor degree in Information Technologies from Universitas Bina Nusantara - Jakarta (UBinus) and received his postgraduate from Marketing Management from Universitas Pelita Harapan - Jakarta (UPH), and he has take doctoral from UPI (Universitas Pendidikan Indonesia) in Education Administration. 